\title{
The End of an Age: William Shakespeare's Troilus and Cressida
}

\author{
Hatice YURTTAŞ*
}

The End of an Age: William Shakespeare's Troilus and Cressida

Abstract

This paper discusses the subversion of the epic and medieval romance tradition through the elements of grotesque realism in William Shakespeare's Troilus and Cressida. The play exposes chivalric values, courtly love, and romance values as invalid forms in the new age that is defined in more mercantile terms. Shakespeare shows the absurdity and hypocrisy of the concept of honor and courtly love ideals of the medieval culture through the fool and the go-between, Thersites and Pandarus, who can be interpreted as elements of grotesque realism of medieval folk culture as Bakhtin describes. For Bakhtin, this festive, carnivalesque spirit is crucial in the emergence of the Renaissance, a new culture with its own set of values and literary forms.

Key Words: Bakhtin, Epic, Courtly Love, Grotesque, The Fool.

\author{
William Shakespeare'in Troilus ve Cressida Adlı \\ Oyununda Bir Çağın Çöküşü \\ Özet
}

Bu makalede Shakespeare'in Troilus ve Cressida adlı oyununda grotesk realizm unsurları aracılığı ile epik ve Orta Çağ romans geleneklerinin alt üst oluşu tartışılmaktadır. Oyun, Troya'nın düşüşü anlatısında kahramanlık, saray aşkı ve romans değerlerinin daha ticari değerleri olan yeni çağda geçersiz olduğunu ortaya koyar. Shakespeare Orta Çağ kültürünün kahramanlık kavramının ve romans ideallerinin ikiyüzlülüğünü, Bakhtin'in anlattığı Orta Çağ halk kültürünün grotesk unsurları olarak okunabilecek, Thersites ve Pandarus adlı soytarı ve arabulucu aracılı̆̆ ile gösterir. Bakhtin'e göre yeni değerleri ve yeni edebi formları ile Rönesans'ın ortaya çımmasında bu şölensel, karnavalesk ruh çok önemlidir.

Anahtar Kelimeler: Bakhtin, Epik, Saray Aşkı, Grotesk, Soytarı.

\section{Introduction}

The classical world, especially the story of Troy was a popular theme, treated and reworked in many French romances, such as The Roman de Troie by Benoit de Saint Maure in late twelfth century and Historai Destructionis Troiae by Guido delle Colonne in the thirteenth century, and it had a great influence over English literature in the Middle Ages (Daiches 1979: p. 52-53). In English literature, alongside Geoffrey Chaucer's poem Troilus and Cresiyde, the story was deployed by William Caxton and John Lydgate before Chapman's translation of Homer's epics appeared in

*Hatice YURTTAŞ, Dr.Öğr.Üyesi., İstanbul Şehir Üniversitesi, İngiliz Dili ve Edebiyatı Bölümü, hatice_yurttas@yahoo.com , ORCID ID orcid.org / 0000-0002-2094-5568 
1598. ${ }^{1}$ However, William Shakespeare's rendition of this famous story with his emphasis over Cressida's unfaithfulness to Troilus, the Trojan prince during the war between the Trojans and Greeks, stands apart from the other narratives. The play has been classified as one of the "problem plays" because of its generic ambiguity (Tillyard, 1993). Since its first publication in the Quarto edition in 1609, the genre of Troilus and Cressida has been ambiguous. The Quarto edition describes the play as a comedy in the preface while the title page presents it as a history. Similarly, the Folio edition is not consistent about the play's genre; it is called a tragedy while it is placed between the history and tragedy plays (Bevington 2004: p. 1-2).

The generic ambiguity of the play arises from the subversion of the epic form and medieval romances. Shakespeare shows the absurdity and hypocrisy of the concept of honor and courtly love in a carnivalesque spirit that announces the death of an age and the birth of a new one. It is through the elements of medieval folk culture, that is the fool, Thersites, who throws a satirical look on the chivalric values and idealism of the medieval culture in the story of the fall of Troy that the medieval values are revealed to be invalid in the new age. In the new age, chivalric values are comic, courtly love is a lie, and material conditions govern love and relationships.

The co-existence of the elements of comedy, tragedy, and history, which pervades to Shakespeare's other plays, especially to Measure for Measure and Twelfth Night as well, can be read as the grotesque realism of the medieval folk culture as Bakhtin describes in his Rabelais and His World (1984). Bakhtin argues that carnivalesque and folk tradition of the medieval times occupies a critical place in the Renaissance literature in that this culture helps build the new literature and the rebirth of the classical works.

The carnivalesque elements belong to a worldview and truth that appears in a certain idiom of symbols and imagery related to the material body as an entity conceived in its existences as that which comes to life, grows up, ages, and dies. These images which constitute the grotesque realism of medieval times highlight the material body in contrast to the body politics, being, and definition of time of the ecclesiastical teaching based on abstract ideas and salvation through the rejection of the body. For Bakhtin, without this carnivalesque philosophy, rooted in pagan rituals and conceptions of the world, that celebrates life, death, and change in the Renaissance, the works of antiquity would have been interpreted through the ecclesiastical ideology. Bakhtin argues that the renewal in this period emerges with the laughter of the festive-spirit and its openness to death-birth cycle that could live in a separate, relatively autonomous place in the medieval times as there is a clear-cut boundary between the official sphere and unofficial sphere (Bakhtin 1984: p. 274). The organization of power with two separate domains allows people to enjoy the counter values and views to the teachings of the church outside but in close proximity of the

\footnotetext{
${ }^{1}$ William Caxton's translation Recuyell of the Historyes of Troye (1464) is the first book printed in the English language and John Lydgate's Troy Book was first printed in 1513 but he finished the poem in 1420.
} 
church. The feasts with gay spirit could take place before or after the official celebrations and feasts even with the participation of the clerics and priests.

In the Renaissance, these two worlds and philosophies undergo a transformation, after which the festive humor enters the canon, the official teaching and literature but in a reduced and transformed way. The imagery of grotesque realism is scattered around in many works during this period but it is only some of the writers who recognize the soil upon which the literature of future could grow and Shakespeare is one of them. According to Bakhtin, Shakespeare's importance lies in his skillful use of the new and the old in his works, in his bringing the folk tradition into the official culture, the canon, in the spirit of rebirth and renewal (Bakhtin 1984: p. 136). With the birth of a new culture, the heroism, ideals, chivalric values, and courtly love traditions of the medieval times become the target of mockery. Men do not perform honorable acts in war, material gain is the strongest motive, and love is only the expression of sexual desire and desire for possession.

\section{Grotesque Elements}

In Troilus and Cressida, the fool, Thersites, belongs to the carnivalesque culture of the medieval times. He represents the bodily aspect of being where the body is most excluded: among the characters striving for honor, immortality, and ideal love in the famous story of the fall of Troy. With his ageing, desiring, eating body, he deconstructs the high flying abstract ideals of the warriors. In addition to Thersites, who, wearing the fool's cap, has the privilege of crowning the play, Pandarus fulfills a similar function. The imagery in their language related to diseases, sex, and culinary brings everything down to earth, to the body, and the body intervenes to show that nothing is eternal, that the body has a life and mortal.

The frequent imagery of boil and the putrefied core in Thersites' railings in addition to his interpretation of the events as "war and lechery" in his railings criticize the discourse of honor (Shakespeare 2004: p. 207). The imagery of a boil, core, putrefaction appear throughout the play to contaminate the chivalric deeds and ideals and it constantly reminds us that beneath the deeds to gain honor and speeches elating honor, there is buried a core that undoes these deeds and speeches. It is the fool who not only knows the core of the war and conflict but also constantly reminds the audience of this and mocks the soldiers. Thersites degrades honor by bringing it back to what it is; his ranting calling "war and lechery" in addition to his frequent mention of venereal diseases imply that the desire for honor and war is a sick desire. The imagery that expresses the conflict between the Trojans and the Greeks is that of the boil or a botchy core. This imagery appears first in Act 2.1 when Thersites seems to be avoiding Ajax's question of the proclamation of the Greek army. This dialogue illustrates Thersites' witty responses and his smart observation of people around him:

Ajax: Thersites!

Thersites: Agamemnon- how if he had boils, full, all over, generally?

Ajax: Thersites! 
Hatice YURTTAŞ

Thersites: And those boils did run (say so), did not the general run, then? Were not that a botchy core?

Ajax: Dog!

Thersites: Then there would come some matter from him. I see none now.

Ajax: Thou bitch-wolf's son, canst thou not hear? Feel, then.

Strikes him.

Thersites: The plague of Greece upon thee, thou mongrel beef- witted lord!

Ajax: Speak, then, thou vinewed'st leaven, speak. I will beat thee into handsomeness.

Thersites: I shall sooner rail thee into wit and holiness; but I think thy horse will sooner con an oration than thou learn a prayer without book. Thou canst strike, canst thou? A red murrain o'thy jade's tricks!

Ajax: Toadstool, learn me the proclamation.

Thersites: Dost thou think I have no sense, thou strik'st me thus?

Ajax: Proclamation!

Thersites: Thou art proclaimed a fool, I think. (Shakespeare 2004: p. 181-183)

Ajax is not aware but Thersites is actually answering his question: the proclamation is that the Greeks are a botchy core and the war is the result of a putrefied core. Ajax is not thought of a smart commander, indeed, there is truth in Thersites' calling him "beef-witted." He is violent and valiant but lacks sense, as his beating the fool and not understanding his wit shows.

Patricia Parker similarly interprets the play's deconstruction of epic ideals and comments on the figure of increase and dilation as emerges in the form of greatness, elation, swelling, dearness as the index of parody of the epic deployed to ridicule the orations in fashion in the theatre. Tracing Ulysses' praise of Ajax' "spacious and dilated parts" in various metaphors and images of swelling, increasing, dilation, she argues that these images subvert the epic greatness and produce the play as a spurious Homeric epic with spurious heroes (Shakespeare 2004: p. 218).

Through his inventive use of grammar and semantics, Thersites subverts the discourse of the epic tradition. On the battlefield, Thersites claims himself illegitimate and hence outside the norms that govern the war in the battlefield. He is as close to the people of high quality physically as he is distant from them mentally and in terms of conduct. He functions as a distorting mirror to the princes and commanders striving for honor, immortality, power, and possession. What he shows in his monstrous reflections, though, is impotency, death, diseases, and weaknesses but these 
reflections are not indicators of a total negative position. Through his legitimate illegitimate voice, we get the sense that transience, renewal, and rebirth is the principle of life.

It is this festive spirit, grotesque realism that makes Shakespeare's plays ambiguous or uncomfortable at moments of violence for the modern reader. The disturbing scene of Malvolio's torture in the darkroom, for instance, in a comedy, in Twelfth Night, makes sense only when we discern the elements of festive spirit which crowns and uncrowns the king, celebrates death that brings life, reacts against idealism, abstraction, prudence, rejection of the materiality of the body, and thus life. Malvolio, who despises the body, pleasure, laughter is thrown into the womb of the earth, descends to the darkness, tortured, mocked, that is, uncrowned so that he can be renewed (Shakespeare, 2008). Death and life, death and birth are phases of being and rejecting this principle deserves to be punished by being made with laughter to experience it in the first hand. The elements of humor and comic in Shakespeare's tragedies, too, are the indicators of the combination of opposites in a holistic world view. The problem of genre in Troilus and Cressida, as is manifest in the difficulty in categorizing the play as tragic, comic, or history shows that Shakespeare's plays reflect a worldview where tragic is not devoid of its comic element and vice versa. The coexistence of laughter and tragic connects Shakespeare to the carnivalesque spirit that deploys tragic and destruction as creative forces in a world perceived in its totality and the human as part of this totality.

Both Thersites and Pandarus are motifs that belong to the medieval festive culture where mock religious sermons are performed by fools during the religious festivals. In Act 2 Scene 3, Thersites wishes syphilis on the Greeks and then leprosy on Patroclus and ends his prayers with amen (Shakespeare 2004: p. 204). Similarly Pandarus performs a mock marriage ceremony playing the priest and finishing with "Amen" when he arranges the meeting of Troilus to Cressida (Shakespeare 2004: p. 241) In both scenes, we see that the seriousness of sermons and marriage ritual meets with mockery and laughter.

Like Feste in Twelfth Night, who speaks the epilogue, Pandarus concludes the play, the feast by involving the spectators in the spectacle. In his speech, he addresses the "bawds" in "the holddoor trade" and remonstrates about not being respected for his work of bringing together lovers when sexual desire is so important that it even causes wars between nations:

Pandarus: A goodly medicine for my aching bones! O world, world, world! Thus is the poor agent despised. $O$ traitors and bawds, how earnestly are you set-a-work and how ill requited! Why should our endeavor be so desired and the performance so loathed? What verse for it? What instance for it? Let me see:

Full merrily the humble-bee doth sing,

Till he hath lost his honey and his sting;

And being once subdued in armed tail,

Sweet honey and sweet notes together fail. 
Good traders in the flesh, set this in your painted clothes:

As many as be here Panders' hall,

Your eyes, half out, weep out at Pandar's fall;

Or if you cannot weep, yet give some groans,

Though not for me, yet for your aching bones.

Brethren and sisters of the hold-door trade,

Some two months hence my will shall here be made.

It should be now, but that my fear is this:

Some galled goose of Winchester would hiss.

Till then I'll sweat and seek about for eases,

And at that time bequeath you my diseases. (Shakespeare 2004: p. 352-354)

Pandarus' epilogue in which he bequeaths syphilis to the spectators and addresses the panders and prostitutes in the audience is a remnant of a long tradition where plays, performances, and feasts encompassed everyone in its festive world. The fool's appearance at the end of the play breaks down the boundary between play and life just as the feast embraces everyone in its world. Unlike the theatre, where the play is performed by a certain group of actors on a bounded space, the festive spirit of the fool captures all in its laughter and abundance. Also, the architecture of the Globe and the frequent remarks on the time and place of the play and appeals to the audience show that the boundary between the actors and the spectators, the play and the real life, or fiction and reality has not been established yet. Frank Kermode notes that the Globe was for professional acting in contrast to the old forms of entertainment but, still, its polygonal shape that is similar to the bear-pits and the common jigs, dancing and singing, or a bawdy dialogue after a tragedy or history play in the Renaissance established a link with the origins of the professional acting. The sword-fighting, the droll, and the jig at the end of a play were elements of the previous forms of performance. Despite the emergence of a different drama in Shakespeare's time, there was also continuity between the old forms of display such as the miracle and morality plays and traveling actors and acrobats and the new form of professional stage (Kermode 2005: p. 95-99).

Troy has to fall and open the path to the new order. Trojan culture was based on agriculture and believed in the values of chivalry whereas the spirit of death and rebirth was at work in the agricultural daily life. The old feudal society was giving way to the young mercantile socioeconomic culture of the middle-class. Hence the Trojan prince, Hector, had to be uncrowned, to be mocked at, thrashed, and killed in a spectacular festivity. He represents the old king of the old order when he is dragged tied to Achilles's horse's tail on the battle field. The scene that disturbs 
the modern reader and is incompatible with either tragedy or comedy is a spectacle of the dead body that announces the coming of the new king, new order, and renaissance. The encounter between Hector and Achilles illustrates the difference between the two; Hector is the chivalric soldier for whom attacking someone disarmed is debasing whereas for Achilles, the brutal soldier, the purpose vindicates any method, he can attack a man even when he pleads fair game. The Trojans are, "ceremonious courtiers" as Agamemnon says, and the feudal society they embody must collapse when the new, mercantile order is pressing (Shakespeare 2004: p. 172).

Bakhtin emphasizes that ignoring the folk tradition in the Renaissance literature can cause misinterpretations. Carolyn Asp, for instance, sees Thersites and Pandarus as "diminishers" who misinterpret the world and the characters (Asp 1978: p. 260). On the contrary, without their judgments, the play would diminish to a great extent because Thersites and Pandarus embody the very intervention of life, sex, and death and they convey the idea of mutability and of hypocrisy of honor in the play. Harold Bloom interprets Thersites as a "normative moralist" on the basis of his complaints against war and lechery and Pandarus as his antithesis (Bloom 1998: p. 330; 333). However, Thersites is not against love; his antagonism is against the hypocritical chivalric ideal of honor and the struggle for eternal fame. Nevertheless, contrary to Carolyn Asp, Harold Bloom recognizes Thersites' importance in the play as the only person whom we can trust; unlike the others, he is a sincere character (Bloom 1998: p. 332).

In the Renaissance, the unofficial folk culture and the ecclesiastical ideology that were separate but in close proximity underwent a transformation. This festive humor entered the canon, the official teaching and literature but in a reduced and transformed way. The imagery of grotesque realism was scattered around in many works during this period but it was only some of the writers who created the soil upon which the literature of future could grow and Shakespeare was one of them.

Although Shakespeare relies on grotesque realism, we also see that its imagery is being denounced or at least in danger of extinction. The sanctity of the fool is breached; Thersites is beaten by Ajax who gets angry at his raillery (Shakespeare 2004: p. 182). Pandarus' initiative fails; his match does not bring happiness or laughter but disappointment and pain to the young lovers, Troilus and Cressida. Troilus condemns Pandarus to ignominy and shame in the last scene. These clues suggest that festivity of the folk culture is losing ground and legitimation. Bakhtin argues that irony, sarcasm, satire survive as remnants of the expression of the bodily principle of the folk tradition. Having lost its contact with the worldview, the festive humor has become individualistic, private, obscene, and erotic, but the philosophy of folk culture tells us that nothing is eternal, that renewal, and rebirth is what is eternal in life.

\section{3. "Madness of Discourse"}

With the collapse of chivalric values and courtly love tradition of the medieval age, love becomes a theme that is explained in monetary, mercantile terms of the newly arising bourgeois culture. Women are reduced to material objects that men fight over and love is nothing more 
than, physical, sexual desire. While Thersites is bringing the ideal of war and honor down to earth, Pandarus is performing a similar part in the discourse of the ideal of love. Troilus' love for Cressida is, after all, only his desire to sleep with her, after which he immediately returns to the public and military matters. In addition, Cressida's speeches expose the vulnerability of women's place within a culture where relationships among men govern the value of women.

As Carolyn Asp and Murat Seçkin also notes, in Troilus and Cressida, Troilus and Cressida's representation as a loyal, loving man and an unfaithful woman is very much problematic (Asp, 1978; Seçkin, 2002). Carolyn Asp interprets this change from the previous versions of the narration of the fall of Troy as the failure of the characters in the play in terms of two different theatrical selves: the emerging theatrical self and personification as practiced in the morality and miracle plays. The new theatrical self as impersonation involves imitating a character in their involvement in daily life, so this impersonation of a character was entangled with the social complexities of life. Asp argues that Cressida and Troilus fail because the social complexities of the period necessarily dissolve the roles of the courtly lady and the courtly lover, the roles which belong to the spiritual world of common values. The characters who personify the ideal characters find themselves in situations where they cannot cope with the practical realities of the time. Transcendence through idealism and art fails.

However, this explanation of the failure in terms of personification seems problematic when we consider Romeo and Juliet, for instance, where courtly love is elated, but there does not appear success or fulfillment and the ideals are again delusive. Also, as will be discussed later in detail, Cressida's speeches are incompatible with the tradition of the courtly love. Cressida expresses selfconsciousness about her role and exposes the hypocrisy of courtly love among violent men.

The mercantile and culinary metaphors that prevail in the play are mostly related to love and women - Helen and Cressida especially. Again as Patricia Parker notes, the metaphors of price and arguments based on mercantile terms reduce the epic greatness to bourgeois values (Parker 2004: p. 319-326). Troilus expresses his desire for Cressida in terms of mercantile and precious goods of a faraway country, India: "Her bed is India; there she lies, a pearl" (Shakespeare 2004: p. 137). When the Trojan soldiers are conferring on the whether to return Helen and end the war, Troilus enthusiastically argues for keeping Helen in mercantile terms:

Troilus: We turn not back the silks upon the merchant

When we have soiled them; nor the remainder viands

We do not throw in unrespective sieve

Because we are full [...] (Shakespeare 2004:p. 194) 
He goes on to compare Hesione whom the Greeks abducted first and thus started the conflict, with Helen in the way a merchant or customer would evaluate the worth of an object:

And for an old aunt whom the Greeks held captive

He brought a Grecian queen, whose youth and freshness

Wrinkles Apollo's and makes stale the morning (Shakespeare 2004:p. 195)

Troilus' reference to Hesione, whom the Greeks abducted to take revenge for Laomedon's having defrauded Hercules over the building of the walls of Troy, manifest how women are turned into tools in the disputes among men. In the context of the market, Troilus clarifies the symbolic value of woman: woman is constitutive of manhood and honor, she is the reason for war and heroic action, and she is the opportunity to glorify oneself, the male self:

She is a theme of honor and renown,

A spur to valiant and magnanimous deeds,

Whose present courage may beat down our foes

And fame in time to come canonize us.

For I presume brave Hector would not lose

So rich advantage of a promised glory

As smiles upon the forehead of this action

For the wide world's revenue (Shakespeare 2004:p. 201- 202).

Troilus' exaggerative oration illustrates the symbolic value of woman in patriarchal culture as constitutive of male subjectivity. Luce Irigaray's interpretation of patriarchal culture as a system based on the exchange of woman as a natural and symbolic value to ensure the autoeroticism and constitution of man is relevant here. Against Levi Strauss' proposition that the exchange of women is the condition of passing from nature to culture and that the rational of the exchange of women instead of men is rooted in the "nature" of women and men, and their tendencies, Irigaray questions the construction of nature and culture in his argument and maintains that this exchange assures the dominance of one sex and one desire, which loves himself and rejects sexual difference (Irigaray, 1985).

In this war waged to get back Helen, wife of Menelaus, the traitor's daughter Cressida is to be delivered to the enemy camp, to get back Antenor, a skillful soldier. When Troilus learns that he will have to separate from Cressida right after they spend their first night together, he fails to grieve and thinks it honorable to obey the verdict. Even though his love for Cressida is convincing, his immediate acceptance of the proclamation that Cressida will be handed over to the Greeks 
manifests a stronger desire. His underlying desire is not for a woman but for himself and other men. His honorable place among men and his relationships with men weigh more heavily. In his introduction to the Arden edition of the play, Bevington discusses how Troilus sacrifices Cressida for public duty and good. To settle the matters with men is more important to him than his commitment to a woman and also as Bevington suggests, this sacrifice gives him the opportunity to behave honorably. Yet honorable conduct of a man should have been to protect his possession/woman at whatever cost as Paris has done (Bevington 2004: p. 42-43). Troilus' lack of action and Paris' sacrifice of his public duty for his possession shows that protecting a woman is not what honor imposes and that honor is rather about the relations among men. Possession of woman becomes a matter of honor if only it will benefit men. If the sacrifice brings a soldier in high demand, Antenor, giving up the possession is regarded honorable.

A Greek soldier named Diomedes takes Cressida to the Greek camp where she is displayed as war booty and "kissed" by the soldiers on her arrival. Troilus visits the camp one night secretly to see Cressida and unfortunately, he witnesses Cressida and Diomedes' conversation as they flirt with each other. Troilus' speech on peeping at Cressida and Diomedes illustrates how the disruption of the ideal woman in his mind disrupts his language:

[...] O, madness of discourse,

That cause sets up with and against itself!

Bifold authority, where reason can revolt

Without perdition, and loss assume all reason

Without revolt! This is and is not Cressid.

Within my soul there doth conduce a fight

Of this strange nature, that a thing inseparate

Divides more wider than the sky and the earth,

And yet the spacious breadth of this division

Admits no orifex for a point as subtle

As Ariachne's broken woof to enter. (Shakespeare 2004: p. 323- 324)

When Troilus' imaginary, ideal woman, Cressida is destroyed, reason and logic of identity is disrupted as well. Cressida as the Greek's booty produces a "madness of discourse." Troilus is shattered in this scene in the face of the reality of what can be interpreted as Cressida's endeavor to gain Diomedes' protection in the enemy camp among violent warriors and her desperate dependence on his love. Troilus' idealism and reason fails but what it produces catches the truth when he realizes that: 
The fragments, scraps, the bits and greasy relics

Of her o'ereaten faith, are bound to Diomed (Shakespeare 2004: p. 324)

It is no surprise that the failure of reason, and oxymoron, contradiction which disrupts the coherency of the play and the characters arrives at its peak point when woman is at stake, for where else the collapse of idealism could be seen better? What Shakespeare represents as woman is a fragmented, scraped being that nevertheless flashes in the male discourse notwithstanding the objectified subjectivity in the language of a boy actor.

While it is clear in this brief picture that Cressida lacks agency to decide for herself or to make any kind of choice, many critics have identified with Troilus in their interpretation of Cressida as an unfaithful lover. The critiques that provide a deeper understanding of Cressida's actions draw attention to the military circumstances of the affair, Troilus' reaction or better lack of reaction to Cressida's delivery to the Greeks, and Cressida's witty, combatant speeches. As Cressida's dialogues with her uncle, Pandarus manifest, she is a witty and intelligent woman not to be gulled by oration or idealism. When Pandarus is trying to praise Troilus comparing him to Hector and describing how handsome he is, Cressida moves between literal and figurative meanings to distort Pandarus' logic and meaning. She frustrates Pandarus' attempts to praise Troilus' complexion in comparison to Paris' referring to Helen's admiration of Troilus, by turning his logic upside down:

Pandarus: She praised his complexion above Paris'

Cressida: Why, Paris hath colour enough.

Pandarus: So he has.

Cressida: Then Troilus should have too much. If she [Helen] praised him above, his complexion is higher than his; he having color enough, and the other higher, is too flaming praise for a good complexion. I had as lief Helen's golden tongue had commended Troilus for a copper nose. (Shakespeare 2004: p. 144)

In this cunning dialogue, Cressida returns Pandarus' language and meaning to himself in an upside down form; she gives back the language she is served to in a distorted form. Apart from this strategic move, she says very little on her own accord except for her soliloquies. Cressida's dialogue with the soldiers at the Greek camp, too, shows her strategic use of language. Cressida is aware of her vulnerable situation in the male-dominated violent world. Delivered to a bunch of brutal soldiers all alone and, as Bevington quotes from Lars Engle, her options being to belong to one man or gang rape, she does not have much choice but obey as she does (Bevington 2004: $p$. 55). Her father having betrayed the Trojans and left for the Greek camp to spare his head, she is left to the protection of her uncle Pandarus who is only eager to present her to Troilus. Murat Seçkin argues that Cressida's witticism as her strategy to fight the male aggression is trespassing to the male domain where the skillful use of language belongs. Her answer to Pandarus' remark on her womanhood and on where her ward lies, she responds: 
Cressida: Upon my back to defend my belly, upon my wit to defend my wiles, upon my secrecy to defend mine honesty, my mask to defend my beauty, and you defend all these; and at all these wards, at a thousand watches. (Shakespeare 2004: p. 153)

Lacking agency and power, Cressida knows that she needs strategies to survive in an aggressive patriarchal society where women become instruments for the disputes and desires among men. Shakespeare derives this implication from Chaucer's Troilus and Criseyde as this poem underlines how the circumstances and material conditions engender actions and desire, especially in Cressida's situation. Criseyde's insecurity in Troy as the daughter of a traitor, her pleading with Hector for her life and safety surrounds her decision to love Troilus. Similarly, her turning to Diomedes at the Greek camp follows Diomedes' reasoning with her that Troy will fall and all Trojans will be destroyed. In contrast to Shakespeare's rendition of the same story, Chaucer's depiction of Criseyde emphasizes the fact that she lacks agency and is subject to the military affairs that devoid her of her right to choose or even speak.

The play we read or watch with women actresses today is necessarily different from the play written for and performed by boy actors in the Renaissance. Lorraine Helms warns that the performance of a boy actor disguised as a woman could have produced various effects, ranging from eroticism to self-reflexivity (Helms 1989: p. 191). While Elaine Showalter suggests that women acting women's part today can produce subversive readings in her analysis of the female characters' speeches, Helms argues that these speeches imply artificiality and distance between the actor and the role with the effect that female subjectivity is delimited and subverted at the moment of its construction (in Helms, 1989: p. 191). This effect is produced through rhymed couplets which are short and, more importantly, are always mediated through a male character. She argues that the rhymed couplets underlie Cressida as a coquettish woman while the syntax in her speeches is obscure and alienated. Cressida's elliptical soliloquy in rhymed couplets, after her dialogue with her uncle in prose, illustrates Helms' point that these speeches obscure the relation of the subject and language. Also, Cressida's speech on her own nature and situation after she gives Troilus' sleeve to Diomedes as a token of her love carries a distanced tone to her womanhood:

Cressida: [...] Troilus, farewell! One eye yet looks on thee,

But with my heart the other eye doth see.

Ah, poor our sex! This fault in us I find:

The error of our eye directs our mind.

What error leads must err. $O$, then conclude:

Minds swayed by eyes are full of turpitude (Shakespeare 2004: p. 320- 321). 
Here, Cressida mimics Troilus when she is interpreting her action by presenting herself as the proof of inconsistent, unreliable female nature. As this is a boy actor mimicking a female, the actor is mimicking a female mimicking a male. Subjectivity and language become a complicated problem. Cressida's speeches look at the subject, woman, herself from outside, from male point of view, which is indeed the actor's point of view. From Cressida's point of view, as discussed above, Troilus has given up on her without so much as a protest and she has only Diomedes to protect her from other Greek soldiers.

\section{Conclusion}

Victor Hugo expresses Shakespeare's uniqueness as the genius preparing the way for the future. For Victor Hugo, geniuses like Shakespeare are defined by a quality of exaggeration, monstrosity, excessiveness and obscurity, and they represent incompleteness, disintegration, obscurity, and change in the moments of crisis. Similarly, another French romanticist, Chateaubriand nominates Shakespeare as one of the mother-geniuses that gave birth to later generations (Bakhtin 1984: p. 123-127). Although these remarks do not take into consideration the folk tradition, they, especially Victor Hugo, highlight the existence of a moment of crisis that opened the way for Western literature to develop in Shakespeare while the German romantics recognized the elements of a different worldview connected to mythology. For Bakhtin, Shakespeare's importance lies in his bringing the folk tradition into the official culture, that is the canon, in the spirit of rebirth and renewal. The crisis in Shakespeare's plays signifies the decline of the ecclesiastical teaching, the medieval culture with its literary forms which could not be possible without the worldview inherent in the folk culture. For Bakhtin, the principles of becoming, change, liberation, and renewal were crucial in overcoming the ecclesiastical hegemony and the renewal in the Renaissance. Shakespeare's importance lies in his skillful use of the new and the old in his works in the moment of change from medieval culture and its values to the new age of bourgeoisie where chivalric values and courtly love cannot survive.

The challenge of Troilus and Cressida in terms of genre ambiguity and lack of catharsis in the end is because Shakespeare crosses across genres and periods with self-consciousness. He brings together the feudal ideals with pre-feudal ideals-the medieval romance and epic- in the Renaissance where both cultures are ending and a new set of values are emerging with the rise of bourgeois economy. The elated discourse of love in Chaucer and the elated epic heroism are clashed in an age when value, love, and honor were placed in monetary and material terms.

\section{References}

Asp, Carolyn (1978). "Transcendence Denied: the Failure of Role Assumption in Troilus and Cressida". SEL. 18.

Bakhtin, Mikhail (1984). Rabelais and His World. Trans. Héléne Iswolsky. Bloomington: Indiana UP. Bloom, Harold (1998). Shakespeare: The Invention of the Human. New York, Riverhead Books. 
Chaucer, Geoffrey (1998). Troilus and Criseyde: A New Translation by Barry Windeatt. Oxford, Oxford UP.

Daiches, David (1970). A Critical History of English Literature 2. New York: Ronald Press Co.

Edmondson III, Henry T. (2006 Summer). "Rethinking the Values of War: The Trojan Battle Deliberations in Troilus and Cressida." Public Integrity Vol. 8. no. 3 pp. 233-243

Helms, Lorraine (May 1989). “Playing the Woman's Part: Feminist Criticism and Shakespearean Performance" Theatre Journal, Vol. 41, No.2, pp.190-200.

Irigaray, Luce (1985). This Sex Which Is Not One. Trans. Catherine Porter with Carolyn Burke. New York: Cornell UP.

Kermode, Frank (2005). The Age of Shakespeare. London: Phoenix.

Parker, Patricia (2004). "Dilation and Inflation: Shakespearean Increase in All's Well ThatEnds, Troilus and Cressida" Bloom's Modern Critical Views: William Shakespeare. Ed. Harold Bloom. Broomal: Chelsea House Publishers.

Seçkin, Murat (2002). "Troilus and Cressida: KressidaNasılKötü Yola Düşer? William Shakespeare'inSahnedeCinselKimlikSorgulaması" IstanbulÜniversitesiEdebiyatFakültesiTiyatro EleştirmenliğiveDramaturjiBölümüDergisi 1.ss. 48-62.

Shakespeare, William (2004). Troilus and Cressida. Ed. David Bevington. London: Thomson Learning HighHolborn House.

Shakespeare, William (2008). Twelft Night, ed. Keir Elam. London: Methuan Drama A\&C Black Publishers Ltd.

Shakespeare, William (2008). Romeo and Juliet. Oxford: Oxford UP.

Tillyard, E.M.W. (1993). Shakespeare's Problem Plays: Hamlet, Troilus and Cressida, All's Well That Ends Well, Measure for Measure. London: Penguin Books. 